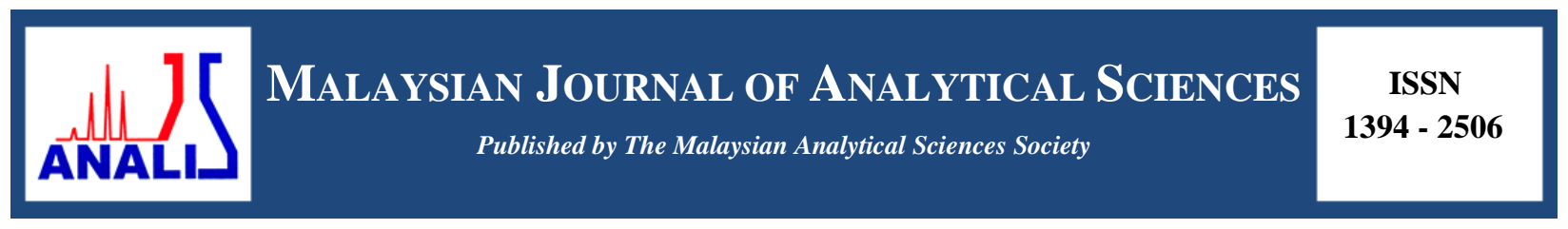

\title{
SYNTHESIS AND CHARACTERISATION OF CHITOSAN-CELLULOSE BIOCOMPOSITE MEMBRANE FOR FUEL CELL APPLICATIONS
}

\author{
(Sintesis dan Pencirian Membran Biokomposit Kitosan-Selulosa untuk Aplikasi Sel Bahan Api) \\ Nur Fatin Ab. Rahman ${ }^{1}$, Kee Shyuan Loh ${ }^{1 *}$, Abu Bakar Mohamad ${ }^{1,2}$, Abdul Amir Hassan Kadhum ${ }^{1,2}$, \\ Kean Long Lim $^{1}$ \\ ${ }^{I}$ Fuel Cell Institute \\ ${ }^{2}$ Department of Chemical and Process Engineering \\ Universiti Kebangsaan Malaysia, 43600 UKM Bangi, Selangor, Malaysia \\ *Corresponding author: ksloh@ukm.edu.my
}

Received: 5 February 2016; Accepted: 22 April 2016

\begin{abstract}
In this work, proton exchange membranes (PEMs) based on chitosan (CS) and cellulose (CL) have been prepared using a solution-casting technique with sulfosuccinic acid (SSA) as an ionic cross linker. The characteristics of these CS-CL biocomposite membranes were studied using scanning electron microscopy (SEM), Fourier transform infrared spectroscopy (FTIR), electrochemical impedance spectroscopy (EIS) in addition to the measurement of the water uptake rate (WUR) and the ion exchange capacity (IEC). The results indicate that the amount of SSA used in this study played a significant role in the proton conduction of the membrane. The proton conductivity of a cross-linked CS-CL membrane was on the order of $10^{-5} \mathrm{~S} \mathrm{~cm}{ }^{-1}$, which is greater than the proton conductivity of a pure CS membrane.
\end{abstract}

Keywords: proton exchange membranes, chitosan, cellulose, biocomposite, membrane

\begin{abstract}
Abstrak
Dalam kajian ini, membran penukaran proton (PEM) berasaskan kitosan (CS) dan selulosa (CL) telah disediakan dengan menggunakan teknik tuangan larutan bersama dengan asid sulfosusinik (SSA) yang berfungsi sebagai pemaut silang ion. Sifat membran biokomposit CS-CL ini dikaji menggunakan mikroskopik pengimbas elektron (SEM), spektroskopi inframerah transformasi Fourier (FTIR), spektrometer elektrokimia impedans (EIS) sebagai tambahan kepada pengukuran kadar penyerapan air (WUR) dan kapasiti penukaran ion (IEC). Keputusan menunjukkan bahawa jumlah SSA digunakan dalam kajian ini memainkan peranan penting dalam pengangkutan proton di dalam membran. Kekonduksian proton untuk CS-CL bertaut silang membran yang diperoleh adalah di dalam lingkungan $10^{-5} \mathrm{~S} \mathrm{~cm}^{-1}$, iaitu lebih tinggi berbanding dengan kekonduksian proton membran CS tulen.
\end{abstract}

Kata kunci: membran penukaran proton, kitosan, selulosa, biokomposit, membran

\section{Introduction}

Recently, fuel cells have been recognised as a prime candidate for new energy resources and have been extensively studied as an alternative to limited fossil fuel resources. Fuel cells have received attention, as they are efficient, clean and eco-friendly power sources [1,2]. Extensive research has been undertaken to develop and prepare a new membrane to prevent a deficiency in currently used perfluorinated membranes (Nafion). This effort includes an expanded search of natural polymers that could produce biopolymer and biocomposite membranes with valuable properties. The use of natural polymer-based membranes became a focus when environmental concerns motivated 


\section{Nur Fatin et al: SYNTHESIS AND CHARACTERISATION OF CHITOSAN-CELLULOSE BIOCOMPOSITE MEMBRANE FOR FUEL CELL APPLICATIONS}

the use of renewable resources for producing clean energy and sustainable consumption and production with the goal to maintain or even improve quality of life [3, 4].

Among all natural polymers, chitosan (CS) and cellulose (CL) are the most important and abundantly available renewable resources on the earth. CS and CL possess many attractive properties such as biodegradable, biocompatible and non-toxic [5,6]. Both CS and CL have similar molecular structure except for the group attached to the $\mathrm{C} 2$ atom. In this configuration $\mathrm{CS}$ has a primary amine $\left(-\mathrm{NH}_{2}\right)$ group, whereas CL has a hydroxyl $(-\mathrm{OH})$ group that can be modify [7].

In this study, CS-CL biocomposites with various amount of sulfosuccinic acid (SSA) were prepared using the casting method to improve their properties as well as the conductivity of the membrane. The main purpose of this research was to develop the biopolymer material for electrolyte membrane.

\section{Materials and Methods}

The following chemicals were reagent grade and obtained from Sigma-Aldrich: chitosan (CS) powder (low molecular weight), $\alpha$-cellulose (CL) powder, acetic acid (glacial $100 \%$ anhydrous for analysis), dimethyl sulfoxide (DMSO) $\left(\mathrm{H}_{2} \mathrm{O} \leq 0.005 \%\right.$ ), and sulfosuccinic acid (SSA) (70 wt. \% in $\mathrm{H}_{2} \mathrm{O}$ ). Deionised water was used during the preparation of the acetic acid solution.

Pre-weighed CS powder was added to $1.0 \mathrm{wt}$ \% aqueous acetic acid solution and was stirred vigorously to form a 1.0 wt. \% CS solution. CL (0.18 g) was dissolved in the DMSO using an ultrasonic stirrer. Both the CS and CL solutions were mix together at a weight ratio of 1: 0.18 and were stirred vigorously using a magnetic stirrer for several hours at room temperature. The CS-CL solutions were mixed with various amounts of SSA $(0.05$ and 0.10 M SSA, labelled as CA05 and CA10, respectively. The mixtures were then continuously stirred and were poured into a petri dish and left to dry at room temperature for 48 hours to form a thin membrane layer. Finally, the biocomposite membranes were dried in an oven at $70{ }^{\circ} \mathrm{C}$ for several hours to remove the solvents. The membrane thickness was in the range of $25-26 \mu \mathrm{m}$.

The surface morphology of the CS-CL biocomposite membranes was characterised using SEM with Carl Zeiss EVO MA10 model at a voltage of $15 \mathrm{kV}$. The membranes were freeze-fractured with liquid nitrogen to expose the edge of the membrane and sputter coated with a thin layer of gold before SEM analysis. The infrared spectra of the membranes were recorded with a model Nicolet 6700 Thermo FTIR spectrophotometer in the wavenumber range of 400 to $4000 \mathrm{~cm}^{-1}$ at a resolution of $4 \mathrm{~cm}^{-1}$.

The water uptake rate of the CS-CL membranes was measured by immersing the membrane samples into deionised water at various temperatures $\left(25,50,70\right.$, and $\left.90^{\circ} \mathrm{C}\right)$ for 2 hours. Then, the membranes were bolted dry with tissue paper and were immediately weighted to determine the initial wet weight. The samples were then maintained in an oven at $120{ }^{\circ} \mathrm{C}$ for 2 hours. The procedure was repeated three times until satisfactory reproducibility was obtained. The water uptake values were calculated according to Equation 1:

$$
\text { Water uptake }(\%)=\frac{(\text { Wwet }- \text { Wdry })}{\text { Wdry }} \times 100
$$

where $\mathrm{W}_{\text {wet }}$ and $\mathrm{W}_{\mathrm{dry}}$ are the wet weight and the dry weight of the membrane, respectively [8].

The IEC values of the membrane sample were determined using a titration method. The sample were immersed in a $1.0 \mathrm{M} \mathrm{NaCl}$ solution for 2 hours followed by titration with a $0.01 \mathrm{M} \mathrm{NaOH}$ solution using phenolphthalein as an indicator [9]. The IEC values were calculated from the titration data using Equation 2:

$$
\operatorname{IEC}\left(\mathrm{mmol} \mathrm{g}^{-1}\right)=\frac{(\mathrm{VNaOH} \times \mathrm{MNaOH})}{\text { Wdry }} \times 10
$$

where $\mathrm{V}_{\mathrm{NaOH}}$ and $\mathrm{M}_{\mathrm{NaOH}}$ are the consumed volume $(\mathrm{mL})$ and molar concentration of the $\mathrm{NaOH}$ solution, respectively. $\mathrm{W}_{\mathrm{dry}}$ is the weight of the dry membrane. 
The proton conductivity of the CS-CL membranes was measured using electrochemical impedance spectroscopy between $10^{-1}$ to $10^{5} \mathrm{~Hz}$ using a Metrohm Autolab potentiostat (PGSTAT128N) equipped with a FRA2 module. The type of cell configuration used in this test is two-electrode AV impedance method in ambient air with relative humidity. The proton conductivity, $\sigma$, was calculated using the Equation 3:

$$
\sigma=\frac{L}{R X A}
$$

where $\sigma\left(\mathrm{S} \mathrm{cm}^{-1}\right)$ is the membrane conductivity, $\mathrm{L}(\mathrm{cm})$ is the thickness of the membrane inside the conductivity cell, A $\left(\mathrm{cm}^{2}\right)$ is the geometric area of the membrane, and $\mathrm{R}(\Omega)$ is the bulk resistance calculated from the highfrequency intercept on the real axis of the complex impedance plot [10].

\section{Results and Discussion}

The morphology of the CS-CL membranes is shown in Figure 1 and represents the cross-sections and the surface of the biocomposite membranes. The cross-sectional micrographs (a) and (b) display the two-phase separation. The CL fibres were visible but well distributed at the bottom of the membranes. These observations provide evidence that the CL fibres were deposited at the bottom layer of the dried membrane after the homogenised biocomposite solution was cast into the petri dish and allowed to dry completely. The phase separation of CS and CL was apparent for all blends indicating that a non-homogenous membrane was obtained. Both biopolymer membranes were brittle. Where, the CS-Cl blend in this study has demonstrated poor miscibility between CS and CL in the samples. Therefore, in this study, CL acted as the filler in the CS membrane used to improve the mechanical strength of the biocomposite membrane. The surface structure of the polymeric blend membranes has a rough structure compared with the morphology of the CS blend membranes reported by Khan et al. [11]. According to his report, CL appeared as shiny white dots in the CS, which could correspond to transverse sections of the CL.
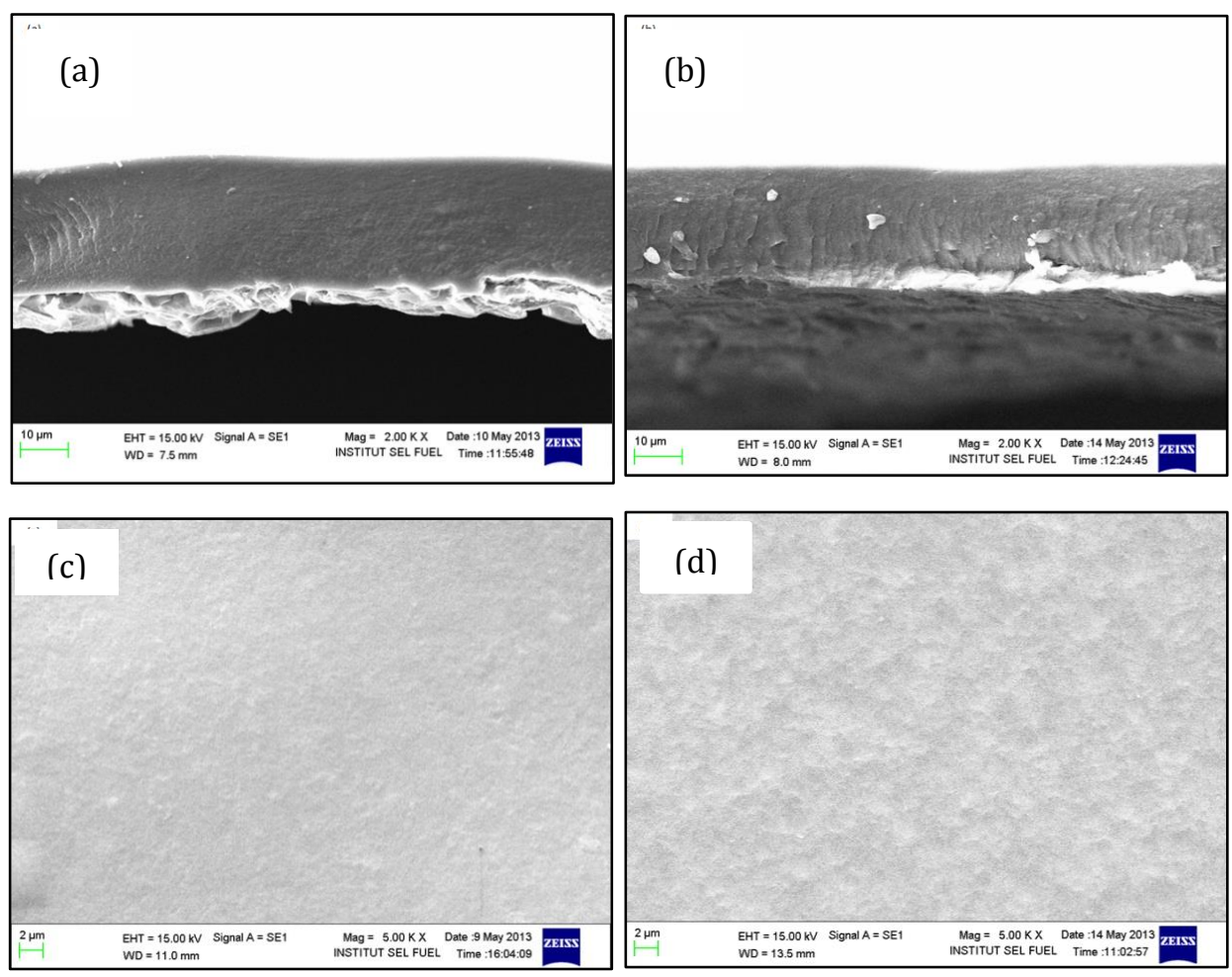

Figure 1. SEM images of the cross section (a) CA05, (b) CA10, and the surface of (c) CA05, (d) CA10 biocomposite membranes. 
The FTIR spectrum (Figure 2) of CS, CL and the biocomposite CS-CL membranes with different amount of SSA were compared to investigate the interconnected structural network formed from linking the functional groups in the membranes. For the CS and CL spectrums, which act as the "control"; there are peaks similar to peaks reported by different authors in the literature [12 - 14]. The CS spectrum showed the presence of absorption bands at 3355 , $2874,1650,1587,1429,1376,1150$ and $1069 \mathrm{~cm}^{-1}$. The band observed at $3355 \mathrm{~cm}^{-1}$ is due to O-H stretching, which overlaps with the NH- stretching in the same region $[11,14]$. The peaks at $2874 \mathrm{~cm}^{-1}$ correspond to $\mathrm{C}-\mathrm{H}$ stretching. The absorption bands at $1429 \mathrm{~cm}^{-1}$ and $1376 \mathrm{~cm}^{-1}$ could be assigned to the $\mathrm{C}-\mathrm{H}$ and $\mathrm{O}-\mathrm{H}$ vibration and $\mathrm{CH}_{3}-$ bending vibrations. The characteristic bands of CS and CL were observed in the spectra of the biocomposite membranes. The spectrum of both the CL and CS showed similar bands with the exception of the absorption bands at 1650 and $1587 \mathrm{~cm}^{-1}$, which correspond to characteristic of $-\mathrm{C}=\mathrm{O}$ stretching (amide I) and $-\mathrm{NH}$ bending (amide II), respectively, as shown in the structure of CS.

The same absorption bands can also be seen from the CA05 and CA10 membranes with slightly significant differences at 1650 to $1646 \mathrm{~cm}^{-1}$ and at 1585 to $1579 \mathrm{~cm}^{-1}$. The basic characteristics of CS were also shown in the CA05 and CA10 membranes, which had bands at $1154 \mathrm{~cm}^{-1}$ and $1155 \mathrm{~cm}^{-1}$ due to the anti-symmetric stretching of the C-O-C bridge. The bands at 1022 and $1029 \mathrm{~cm}^{-1}$ were the skeletal vibrations involving C-O stretching. Indeed, a band observed in that region is assigned to the amide group of the CS polysaccharide structure [15]. From the CA05 and CA10 spectra, a new band was being observed in the range from 1350 to $1000 \mathrm{~cm}^{-1}$, which represents C-N interactions. Moreover, the absorption bands near $1250 \mathrm{~cm}^{-1}$ indicate the presence of the sulfonic acid group caused by the introduction of SSA. Therefore, from the FTIR spectrum of the samples, the cross linking reaction occurs primarily between the amine group in the chitosan and the carboxylic group in the SSA [16]. There was likely no interaction occurs between CS and CL functional group. These interactions are more towards a physical interaction rather than chemical interactions.

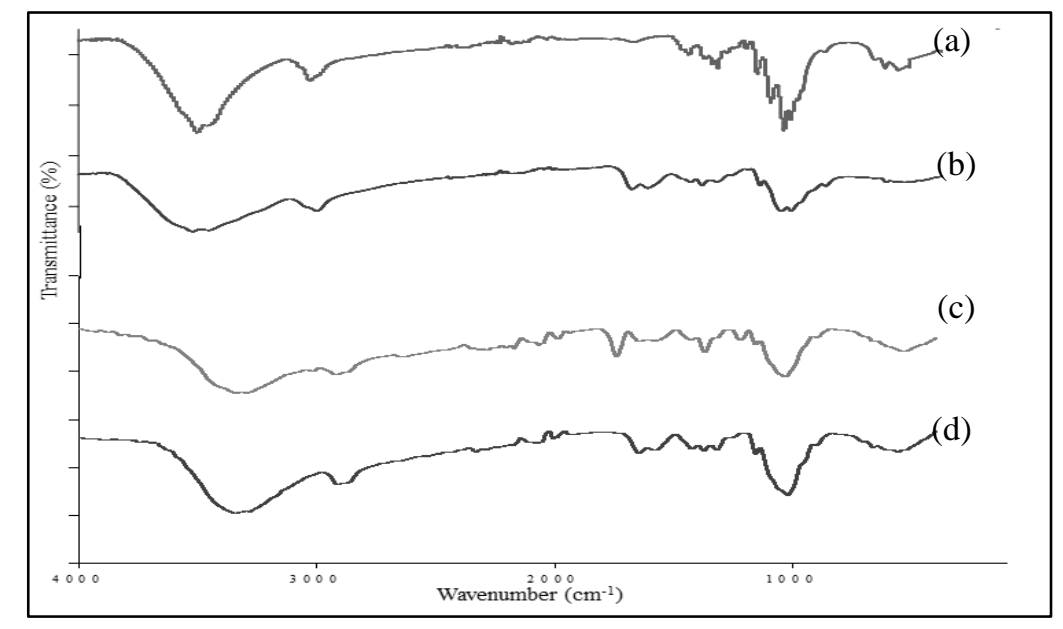

Figure 2. The IR spectra of (a) cellulose (b) chitosan (c) CA05 and (d) CA10.

Table 1 shows the results of water uptake for Nafion 212, CA05 and CA10 membranes. When considering the water uptake properties, the transport of protons in the sulfonated polymer membranes is greatly affected by the presence of water molecules [17]. The membrane water uptake has been determined at four different temperatures. Table 1 shows the trend that the water uptake of the biocomposite membranes increased with an increased temperature, which is similar to the Nafion membrane. As a result, water uptake of the cross-linked CS-CL was found to be multiple times greater than the Nafion 212 in the temperature range between 25 and $90{ }^{\circ} \mathrm{C}$. The CA05 and CA10 membranes possessed greater hydrophilic characteristic compared with the Nafion membrane due to the presence of three polar functional groups. CS is highly capable of forming a hydrogen bond with water and trapping water in its 
structure [8]. This result is in contrast with the Nafion membranes, which have both hydrophilic and hydrophobic zones and contain polar hydrophobic (C-F bonds) and polar functional groups (C-O-C linkages). The concentration of the cross-linking agent also influenced the water uptake capacity of the membranes. The CS-CL membrane that contained 0.05 M SSA exhibited greater water uptake than the membranes that contained $0.10 \mathrm{M} \mathrm{SSA}$. With an increase in the concentration of SSA, the membranes became more rigid and structurally compact, and this may have caused the free volume of water molecules retain in the structure to decrease.

Table 1. The water uptake rate of membranes in various temperatures

\begin{tabular}{lccc}
\hline \multirow{2}{*}{ Temperature $\left({ }^{\circ} \mathbf{C}\right)$} & \multicolumn{3}{c}{ Water uptake $(\%)$} \\
\cline { 2 - 4 } & Nafion 212 & CA05 & CA10 \\
\hline 25 & 9.0 & 64 & 34 \\
50 & 11.8 & 71 & 54 \\
70 & 16.0 & 87 & 61 \\
90 & 16.3 & 104 & 78 \\
\hline
\end{tabular}

Table 2 shows the IEC values of Nafion and the CS-CL biocomposite membranes. The IEC value is the opposite of the water uptake results. The IEC values for Nafion 212 and CA10 membranes decreased due to an increase in the condition temperature. Rhim et al. has reported that at low operating temperature resulted in more cation exchangeable sites due to the unreacted carboxylic acid groups in the SSA [16]. Conversely, the CA05 membrane, IEC increased with an increase in the temperature. This result could be attributed to the increment of charge carriers and closely related to the rigidity of the molecule structure. An increase in the IEC values (interpreted as an increase in the number of sulfonic acid groups within the polymer matrix) will not necessarily increase the water uptake values. Therefore, the amount of cross linker added to a polymer electrolyte membrane is not a dominant factor of the increase in the proton conductivity [16]. It can be concluded that the degree of cross linking in the membranes affected significantly their proton conductivities.

The proton conductivity measurements were carried out to study the effect of cross-linking and the temperature of the operating system on the electrical properties of the CS-CL membranes. The conductivity of the CS-CL membranes has shown in Table 3. As seen in Table 2 and Table 3, the conductivity of the membranes followed a similar trend with the IEC, as it is believed that increasing the amount of SSA in the membrane could lead to significant improvement in the proton conductivity of the membrane due to the increase in proton carriers by the sulfonic acid group $\left(-\mathrm{SO}_{3}{ }^{-} \mathrm{H}^{+}\right)$. Even though the conductivity of the CS-CL membranes in this study has a lower value than other membranes, the conductivity is still an improvement compared with a pure CS membrane. There is potential to obtain greater proton conductivity through modification of the CS structure.

Table 2 The ion exchange capacity of the membranes in various temperatures.

\begin{tabular}{lccc}
\hline \multirow{2}{*}{ Temperature $\left({ }^{\circ} \mathbf{C}\right)$} & \multicolumn{3}{c}{ Ion exchange capacity $(\mathbf{m m o l} / \mathbf{g})$} \\
\cline { 2 - 4 } & Nafion 212 & CA05 & CA10 \\
\hline 25 & 1.57 & 0.49 & 2.00 \\
50 & 1.47 & 0.69 & 2.04 \\
70 & 1.18 & 0.74 & 1.25 \\
90 & 1.41 & 1.22 & 1.03 \\
\hline
\end{tabular}




\section{Nur Fatin et al: SYNTHESIS AND CHARACTERISATION OF CHITOSAN-CELLULOSE BIOCOMPOSITE MEMBRANE FOR FUEL CELL APPLICATIONS}

Table 3. Ionic conductivity of the membranes at room temperature condition

\begin{tabular}{lc}
\hline Membranes & Proton conductivity $\left(\mathbf{S ~ c m}^{-\mathbf{1}}\right)$ \\
\hline Nafion 212 & $5.96 \times 10^{-3}$ \\
CA05 & $2.30 \times 10^{-5}$ \\
CA10 & $4.73 \times 10^{-5}$ \\
\hline
\end{tabular}

\section{Conclusion}

CS-CL biocomposite polymers cross-linked with various amount of SSA have been prepared and evaluated as a potential polymer electrolyte membrane for fuel cell applications. CL has been shown to be filler that strenghthens biocomposite membrane. Further study will be focusing on conductivity using different types of ionic crosslinker agent. Specifically, SSA has improved the proton conductivity of the CS membrane from $\sim 10^{-9}$ to $\sim 10^{-5}$ by introducing a cross linking agent and an ionic carrier in the biocomposite membrane. The proton conductivity was found to be dependent on the concentration of the ionic cross linker.

\section{Acknowledgement}

The authors gratefully acknowledge the financial support provided for this work by the Universiti Kebangsaan Malaysia through the Research Universiti Grants GUP-2011-374, DLP-2013-038, and DIP-2014-002.

\section{References}

1. Higashihara, T. Matsumoto, K. and Ueda, M. (2009). Sulfonated aromatic hydrocarbon polymers as proton exchange membranes for fuel cells. Polymer, 50: $5341-5357$.

2. Lee, D. C., Yang, H. N., Park, S. H. and Kim, W. J. (2014). Nafion/graphene oxide composite membranes for low humidifying polymer electrolyte membrane fuel cell. Journal of Membrane Science, 452: 20 - 28.

3. Vilaplana, F., Strömberg, E. and Karlsson, S. (2010). Environmental and resource aspects of sustainable biocomposite. Polymer of Degradation and Stability, 95: 2147 - 2161.

4. Pereda, M., Amica, G. and Marcovich, N. E. (2012). Development and characterization of edible chitosan/olive oil emulsion films. Carbohydrate Polymers, 87: 1318 - 1325.

5. Kaco, H., Zakaria, S., Razali, N. F., Chia, C. H., Zhang, L. and Jani, S. M. (2014). Properties of cellulose hydrogel from Kenaf core prepared via pre-cooled dissolving method. Sains Malaysiana, 43(8): 1221 - 1229.

6. Wirach Taweepreda. (2014). Dynamic mechanical and dielectric properties of modified surface chitosan/natural rubber latex. Sains Malaysiana, 43(2): 241 - 245.

7. Zakaria, S., Chia, C. H., Ahmad, W. H. W., Kaco, H., Chook, S. W. and Chan, C. H. (2015). Mechanical and antibacterial properties of paper coated with Chitosan. Sains Malaysiana, 44(6): 905 - 911.

8. Ma, J., Sahai, Y. and Buchheit, R. G. (2012). Evaluation of multivalent phosphate cross-linked chitosan biopolymer membrane for direct borohydride fuel cells. Journal of Power Sources, 202: 18-27.

9. Thiam, H. S., Daud, W. R. W., Kamarudin, S. K., Mohamad, A. B., Kadhum, A. A. H., Loh, K. S. and Majlan, E. H. (2012). Nafion/ $\mathrm{Pd}-\mathrm{SiO}_{2}$ nanofiber composite membranes for direct methanol fuel cell applications. International Journal of Hydrogen Energy, 38: 9474 - 9483.

10. Ma, J., Choudhury, N. A., Sahai, Y. \& Buchheit, R. (2011). A high performance direct borohydride fuel cell employing cross-linked chitosan membrane. Journal of Power Sources, 196: 8257 - 8264.

11. Khan, A., Khan, R. A., Salmieri, S., Tien, C. L., Riedl, B., Bouchard, J., Chauve, G., Tan, V., Kamal, M .R. and Lacroix, M. (2012). Mechanical and barrier properties of nanocrystalline cellulose reinforced chitosan based nanocomposite films. Carbohydrate Polymers, 90: 1601 - 1608.

12. Pavia, D. L., Lampman, G. M. and Kriz, G. S. (2001). Introduction to spectroscopy: A Guide for students of organic chemistry. United States: Thomson Learning, Inc.

13. Yin, J., Luo, K., Chen, X. and Khutoryanskiy, V. V. (2006). Miscibility studies of the blends of chitosan with some cellulose ethers. Carbohydrate Polymers, 63: 238 - 244.

14. Stefanescu, C., Daly, W. H. and Negulescu, I. I. (2012). Biocomposite films prepared form ionic liquid solutions of chitosan and cellulose. Carbohydrate Polymers, 87: 435 - 443. 
15. Ávila, A., Bierbrauer, K., Pucci, G., López-González, M. and Strumia, M. (2012). Study of optimization of the synthesis and properties of biocomposite films based on grafted chitosan. Journal of Food Engineering, 109: $752-761$.

16. Rhim, J., Park, H., Lee, C., Jun, J., Kim, D. and Lee, Y. (2004). Crosslinked poly(vinyl alcohol) membranes containing sulfonic acid group: proton and methanol transport through membranes. Journal of Membrane Science, 238: 143 - 151 .

17. Ahmad, H., Kamarudin, S. K., Hasran, U. A. and Daud, W. R. W. (2010). Overview of hybrid membranes for direct methanol fuel cell applications. International Journal of Hydrogen Energy, 35: 2160 - 2175. 